(4) This, the second volume of a handbook of the birds of Denmark, deals with the divers, grebes, petrels, rails, and waders. The characters of the various species are indicated in key-tables, summer and winter plumages are described, a. lengthy section gives an account of the migrations, habits, and status in Denmark of each species, and each description is accompanied by an excellent illustration in half-tone of the bird itself.

J. R.

\section{Systematic Zoology.}

Handbuch der Zoologie: eine Naturgeschichte der Stämme des Tierreiches. Gegründet von Prof. Dr. Willy Kükenthal. Herausgegeben von Dr. Thilo Krumbach. Vierter Band: Progoneata, Chilopoda, Insecta. Erste Lieferung. Pp. 128. 13 gold marks. Zweite Lieferung. Pp. 129-240. n.p. Fünfter Band: Solenogastres, Mollusca, Echinodermata, Tunicata. Dritte Lieferung. Pp. 177-256. 8 gold marks. (Berlin und Leipzig : Walter de Gruyter und Co., 1926.)

THE fourth volume of Kükenthal's treatise opens with a short explanation of the extinction of the term Myriapoda, which has lost its strict systematic significance.

After a definition of the class Progoneata, the author, Dr. Carl Graf Attems, passes to the consideration of the constituent subclasses - Symphyla, Pauropoda, and Diplopoda-their anatomy, developmental stages, ecology. distribution, and classification. The sections on the Symphyla and Pauropoda are short-each about 9 pages - but that on the Diplopoda extends to more than 200 pages, and gives an admirably complete account of this subclass and its affinities. The classification is done in great detail-into orders and then into genera. The space devoted to systematics is disproportionately large, and we hope it may not result in restricting the pages available for the account of the Insecta in the later part of the volume. The parts are well illustrated, and at the end of the account of each class is a list of works of reference.

The first quarter of section 3 of vol. 5 contains the conclusion of the account-the development, ecology, and classification-of the Bivalvia. The rest of the part is devoted to the Cephalopoda, the description of which by Prof. J. Thiele is on the lines of the two preceding parts of the volume already noticed in NATURE. He gives a fair account of the anatomy, but finer structural details receive insufficient consideration, and reference to some of the newer work is lacking, for example, to the recent views on symbiotic organisms in relation to the luminous organs, to the details of formation and discharge of the remarkable spermatophores, and to the young stages of Spirula.

More illustrations would have been welcome in this section; particularly of important aspects such as the egg-cleavage and latər stages of development, and the histology of the statocysts, eyes, and chromatophores.
Die Tierwelt der Nord-und Ostsee. Herausgegeben von G. Grimpe und E. Wagler. Lieferung 5. Teil 9. $\mathrm{d}_{1}$ : Lamellibranchia, von F. Haas; Teil 12. $a_{1}$ : Copelata, von A. Bückmann. Pp. $96+20$. (Leipzig : Akademische Verlagsgesellschaft m.b.H., 1926.) $8 \cdot 80$ gold marks.

These new parts of " Die Tierwelt der Nord- und Ostsee" maintain the high standard set by those already published. The greater part consists of a well-balanced account of the lamellibranchs by F. Haas; it is perhaps to be regretted that he uses the older classification based mainly on the teeth and hinge of the shell, rather than the newer classification by means of the gill structure, but he provides what will be of great service to the marine biologist, namely, good keys to the genera and species. There is an interesting account, illustrated with good tables, of the distribution of all the species and, in addition, a very brief summary of the present state of our knowledge regarding their structure and physiology is included.

The bionomics of the lamellibranchs-a subject of the utmost importance-are given due prominence by the author, both from the ecological and utilitarian points of view. Limnoria, however, is better considered as the precursor than as the enemy of Teredo, although the author admits that if it increased at the expense of Teredo "Teufel durch Beelzebub ausgetrieben würde."

The concluding pages of the parts before us are devoted to a short and very clearly illustrated account of the Copelata (Appendiculariæ), which has been contributed by A. Bückmann.

Les arachnides de France. Par Eugène Simon. Tome sixième. Deuxième partie: Le synopsis général et le catalogue des espèces françaises de l'ordre des Aranece (suite). CEuvre posthume publiée par L. Berland et L. Fage. Pp. $\ddot{\text { ii }}+$ 309-532. (Paris: L. Mulo, 1926.) 25 francs.

THIs part does not complete the supplement to "Les Arachnides de France." It deals with two sub-families of the Argiopidæ-the Theridiosomatinæ and Erigoninæ. The former contains the genus Theridiosoma, which is in some respects a link between the Theridiidæ and Argiopidæ and is represented in France and Great Britain by one species only. In the Erigoninæ thirteen new genera have been created without the addition of any new species, which seems somewhat drastic treatment. Some of the generic distinctions are slight and the generic characters will in some cases be more difficult to determine than the specific ones.

This part will be something of a disappointment to British arachnologists, who have been anxiously awaiting the remainder of this volume in the hope that the British and European classification of spiders might once and for all be unified. It is certainly a valuable contribution but falls short of our hopes. 